$628.977 .1: 620.16$

\title{
検查照明の分類と実 例
}

\section{1. 検查照明の範囲}

検査照明と称するものの範囲はいまだ明確には定義さ れて居らない，物指の目盛を読み易くするための照明と か，指針の位置を見易くするための照明などまでも，検 查照明とするなら余りにも範囲が広くなり，ことさら一 般の生産照明と区別して考える必要が無くなるである う.それでここでは一応視検査で作業が容易になると か，可能になるとかの点で特別の考虑が払われた照明を 検查照明とし，投影拡大器，比色計など光学器具または 計測器を用いる検査なども除外することにする.

\section{2. 検查照明の分類}

視作業はそれが普通一般の作業であれ，検查作業であ れ，視野の中から対象としている物または物の部分を他 と区別して見る事が基盤となっているので物の見え易さ が照明方法を決定する要因となるのは当然である.

さて物の見え易さを左右する要件は幾多あるが，特に 重要なのは周知の通り,
a. 対象とする物または物の部分の大さ
b. その明るさ
c. 物または物の部分と，その背景間の明るさ，色な どの対比

d，対象を注視しうる時間

などである、したがって検査照明の手法はこの四要素な どのうち，どれを向上する目的かということで分類して 考えられ，照明設計に当ってもまずこれを確認する事が 䀒要と思われる。

検査照明はまた光源の種類から，
a、自然光を用いるもの
b. 一般の照明に使用せられる光源を用いるもの
c. 特殊光源（紫外線, 偏光なぞも含めて特殊目的の ため作られたり，組合されたりした光源）を用いる ものなどに分類する考え方もあり，さらにまた照射法に よって,
a. 反射光を用いるもの
b. 透過光を用いるもの

\section{† Classification and Examples of Lighting for Inspection}

* 大阪府立産業能率研究所

\section{正会員 中 村 正 躬*}

に二分され，あるいは検查目的に応じる光質についての 要求から,

a. ごく一般的な局部照明

b. 指向性光源によるもの

c. 拡散性光源によるもの

\section{と三分類する事も出来る.}

\section{3. 検査照明の主な手法}

従って上記の分類に応じた各種の組合せによって幾多 の照明手法が生れるが, 便宜上
a, 自然光による検査照明
b. 一般局部照明による検査照明
c. 指向性光源による検查照明
d. 拡散性光源による検査照明
e. 特殊光源, 特殊手法による検査照明

に大別し、その性質と実例とにつき概説することとする。

\section{1 自然光による検查照明}

北空光は南空光より量, 質ともに安定しているので, 従来広く検查照明に用いられ,基準にもされて来た。.しか 乙検査量の増加と, 検查程度の向上について年々要求が 高まり，北空光による検査法では次第に満足されなくな って来た. 幸い光源とその照明技術の進歩により近時各 種の天然色光源が研究され北空光にとってかわりらつあ るが,それ程精密度を要求されない場合とか,比較検査の 埸合にはいまだ自然光による検査が広く行われている。

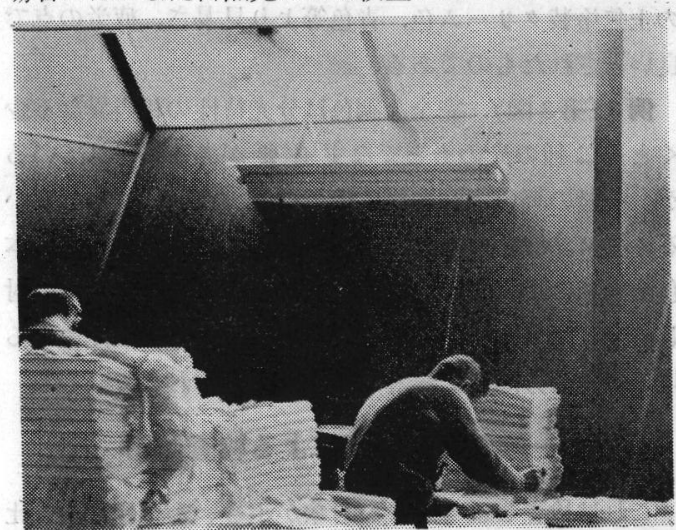

第 1 図縮緬の検査・整理作業 （浜縮緬工業協同組合） 


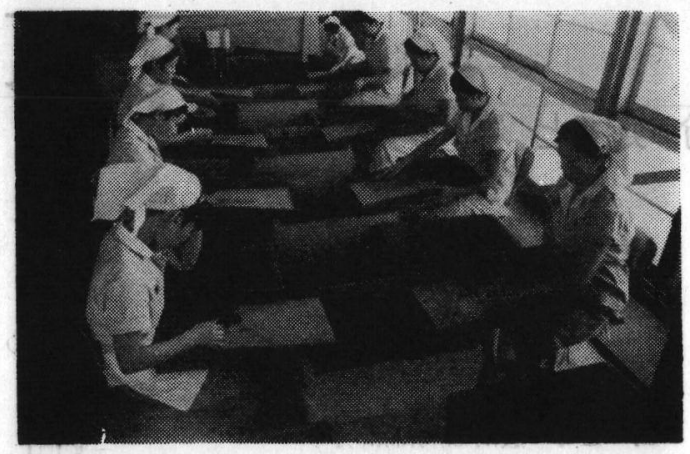

第2図丸薬の整粒作業 （森下仁丹株式会社）

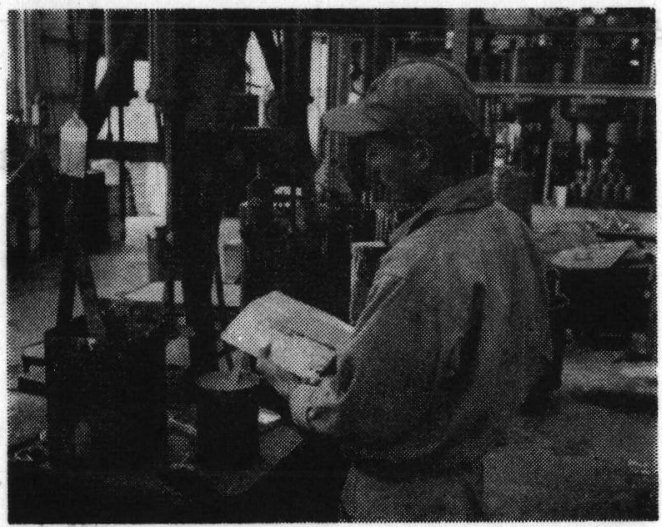

第3図ペンントの調色作業底 | \& (関西ヘイント株式会社)

例 1 (第 1 図) 工場北側に張出し天空を設け, 自然光 により縮緬の検查を行つている例で，作業面照度は晴天 で約 $5001 \mathrm{x}$ ，図に見えるけい光灯 (灯種不詳) は照度不 足の㭙係用するもの.

例 2 (第 2 図) 銀粉塗布以前の仁丹を箕型容器に入れ 異形のものをぬきとる. 北空光を利用し容器の底は裏面 を薄緑色に塗装したすりガラスで，この薄緑色は，実験 の上無塗装クリーム色, 青色等より見易さ, 疲労の点で 良いとされたものである。

例 3 (第 3 図) 完全な調色は分光特性の相当異なる少 くとも二種の光のもとでなす必要があるとされている が，一般の調色は図の様に簡単に自然光で行われてい る. $8 \times 20 \mathrm{~cm}$ のブリキ板に叙装したものを用い，見本 色の塗板や標準色票と比較して調色する．板は水平に対 し約 $45^{\circ}$ 傾ける事と室内の照明光が入らぬよう注意する 以外は空の力向, 天候等にも無考虑で行われている.

\section{2 一般の局部照明による検査照明}

これは検査しようとする対象が小さいか背景との刘比 が小さい时照度を向上して見易くする場合とか，検査物 の形状周囲の状況などにより一般照明では検查が困難な
時利用される手法で，普通の作業灯と同様光質には特別 な要求をしないが, 器具構造配置の選定に当って, まぶ しさとか，照度の異常分布により，快適度を損じないこ と，作業の邪魔になったり手暗がりにならぬことなどを 考虑する必要がある.

例 4 (第 4 汹) メリヤス針の検查 項目は揃の状態, ラッチの動き, 針面の平滑度, 歪および外観などである が，工業用メリヤス針は特に小寸法で検查が困 難であ る.この例では $60 \mathrm{~W}$ 白熱灯を強照型のかさに入れててい るが，小さいラッチの状態を検查するにはけい光灯より

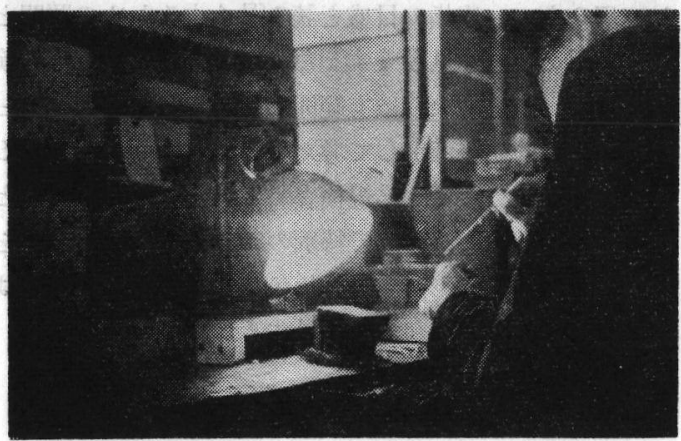

第 4 図工業用メリヤス針の検查 （石脇精密工業株式会社）

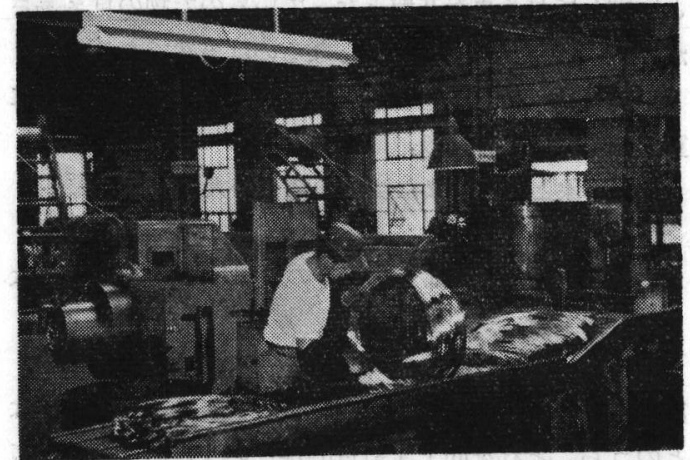

第 5 図裸銅線 表面検查

（住友電気工業株式会社）

白熱灯の方が適しているようである.

例 5 (第 5 図) 直径 $1.6 \sim 9 \mathrm{~mm}$ の裸銅線の検査は,従 来図の右側に見えるとおり $100 \mathrm{~W}$ 昼光電球を用いていた が，40W 㡺光色けい光灯の方が適している事が判った ので順次置換えられつつある. 作業面照度 350 4001x. 同社では細い錫引線も $40 \mathrm{~W}$ 㡺光色けい光灯 2 本を耐酸器 具に入れたもので照射し巻取部で色，きづな゙を検査し ている. 作業面照度 $4001 x$.

例6（第6図）傾斜した検查台上を下から上へ布を 流し、きづ,污れなどを検査する方法で, 20W 2 灯用器具 2 台に㡺光色けい光灯が入れてある. 作業面照度は 550 $\sim 7001 \mathrm{x}$ 


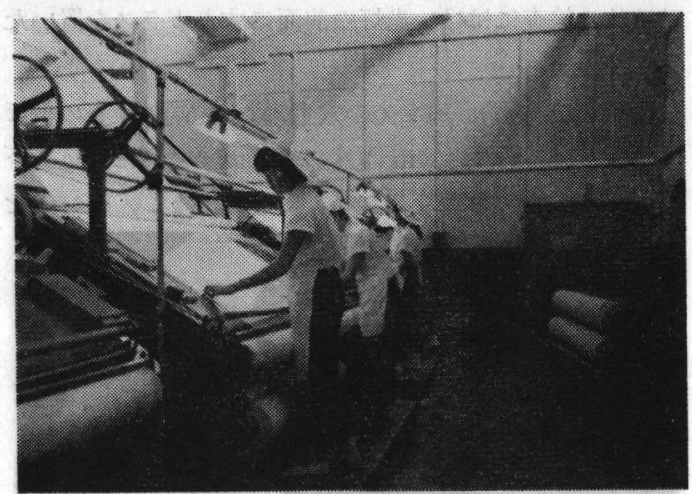

第6図榆反照明 （敷島紡績株式会社）

その他水槽試験では水中に光源を設置すれば気泡状態が 明膫になり，外部照明ではどうしても陰になる場所，例 えばボンべの内面検査には長い柄の先に白熱灯をつけ， それに保護金網とかさを設けた一種のハンド・ランプを 使用するなどがこの分類に入ろう.

\section{3. 指向性光源による検査照明}

この方法は特に非鏡面材の表面きづ. 凸凹・ポンチマ ーク・搔痕・ひび制れなどの平面上の不規則箇所の検出に 用いられる. 指向性をもった光線が検査しようとする物 に斜にあたると不規則筒所が明るい部分と陰の部分とに 照らし出され，明暸に見えるのである.（第7図,第8図 参照)

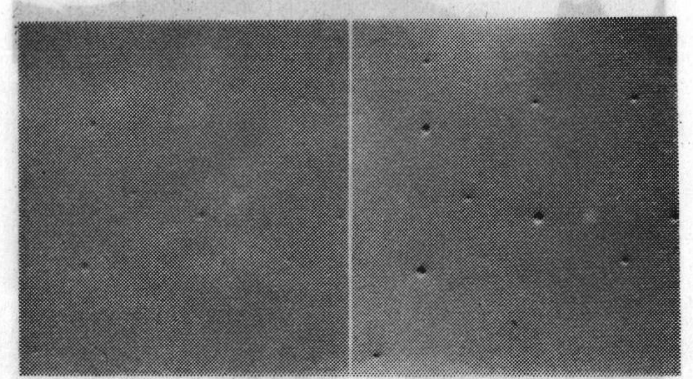

(i) 水平照射

(ii) $45^{\circ}$ 照射

第7図明るさの対比と見易さ（その一）

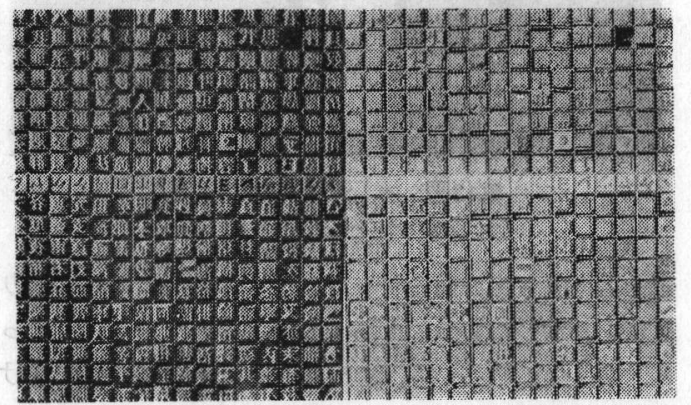

(i) 水平照射

(ii) 垂直照射

第8図明るさの対比と見易さ (との二)

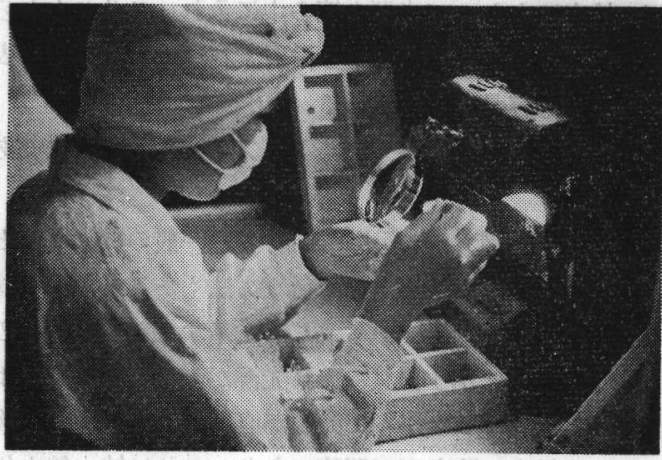

第9図アンプルの検査

（塩野義製薬株式会社）

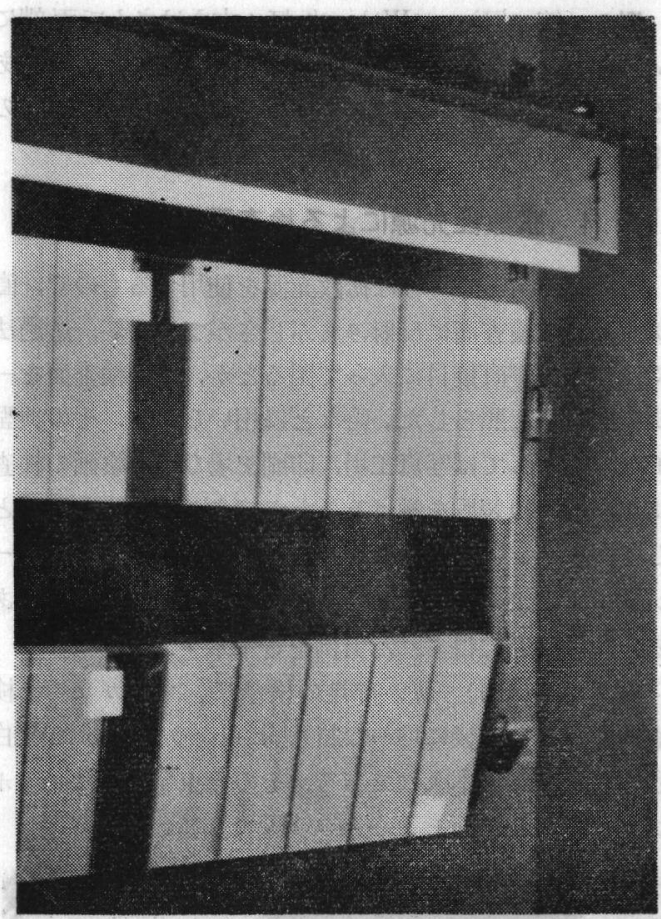

第10図: 綿 糸のケパ検 査 (日本紡績検査協会)

鏡面体もこの方法で検査できる.この場合は検查面は 作業者に暗く見えるが不完全な所は光を反射して明るく 見える.何れの場合にも注意を要するのは光源自体や反 射光が作業者や他の人の邪魔にならぬように光源の位置 と方向を選ぶことである。

希望する指向光線をうるには器具として特種な反射 器，レンズを使うとか,光源としてスポット・ランプを使 うのが通例で，自動車用霧中灯を水平に数個並べて紙の 表面検査を行っている例とか，150W の反射型投光電球 を下向きに亚べて食刻覀鉛板の精密検査を行っている例 とかが外国資料に見られる.

光線の全反射を上手に利用したるのに端面照明とでも いらべきものがある.ガラス・プラスチックなどの透明 
板の検査にあたって光源を箱の中に入れ，スリットから 出る光を被検査物の端面から投射すれば内部の気泡も表 面のきゔも容易に検出される。

次の例はこれと類似の方法によるアンプルの検査法であ る.

例 7 (第9図) アンプルの検査は一般のビン検査と 同様拡散光源を用い透過法で行う方法もあるが，検查刘 象が小さいので困難である，ここに示す方法は $60 \mathrm{~W}$ の 白熱電球を図に示す器具に入れ光源が上から下に走るよ うにしてある．したがって光源が直接目に入らず，異物 による反射光・陰などが明瞭になり，これに拡大鏡を併 用している。

例 8 (第10図) 40Wけい光灯4本をはさんで両端に 60W白熱電球 1 個をおき，下面にすりガラスが入れてあ る、これは糸のケバの状態を検査する照明装置で一種の 指向性照明である. 検査面照度 60〜70 lx.

\section{4 拡散性光源による検查照明}

広面積の明るさ一様な拡散光源を使用するもので，直 接光源では検査面に反射のまぶしさがでるとか，透過法 では強い光が直接目に入って困るとか，広い検査面を一 様の明るさで照らしたい時などに用いられる。その典型 的なものとしては写真工場, 印刷工場などの陰画の検查 に用いる透視装置を挙げることができる. 特殊な用法と してパターンのついた拡散光源で金属板を照らしパター ン像の歪によって面のきづ，凹凸を検出する例などがあ る. 次に手近に得られた実例を若干示す.

例 9 (第11図) 薄い布地の検査で, すりガラスを検 查面としその背後に均一な照度分 布をうるため $10 \mathrm{~W}$ 白 色けい光灯が 6 本入れてある. その光束発散度は 40 番ポ プリンを通した面で 250〜400 rlxである.

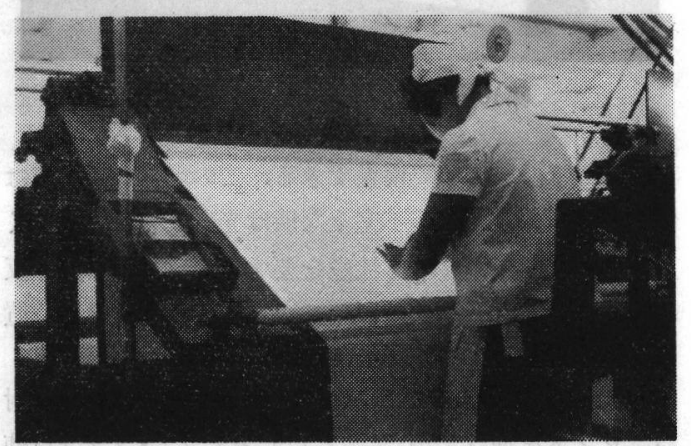

第11図検 反 照明 （敷島紡績株式会社）

例10 (第12図) ビン詰の緑色透明化粧 液検查用の照 明器具で, 内面に黒色ラシヤ紙(白色ではまぶしすぎる) を張った箱の上下にそれぞれ10W白色けい光灯が1本入 れてあり，空はビン形にあけてある.しかし一般にビン
詰液体の検査にはけい光灯の前面にすりガラスを置いた ものが多い.

例11 (第13図) ペン先の穴位置, 先端の検查の例で 机上の一部に $5 \times 10 \mathrm{~cm}$ 内外のすりガラスをはめ込み下 に 5 Wの乳白豆電球を入れたものを光源とし, ペン先を

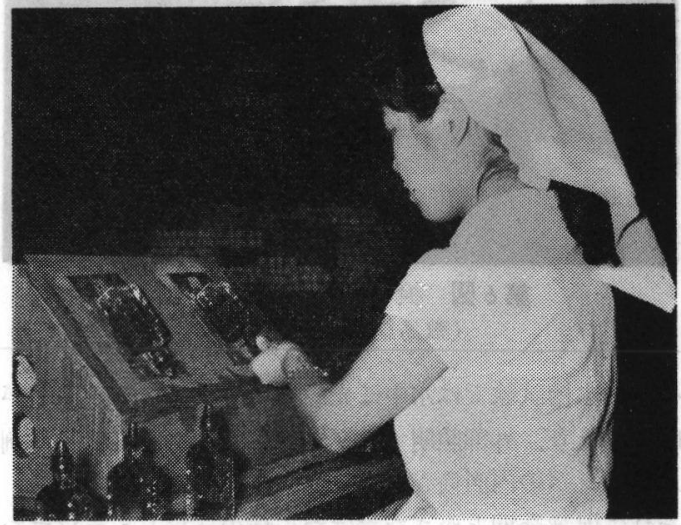

第12図ビン詰液体化粧品の検査 （株式会社 中山太陽堂）

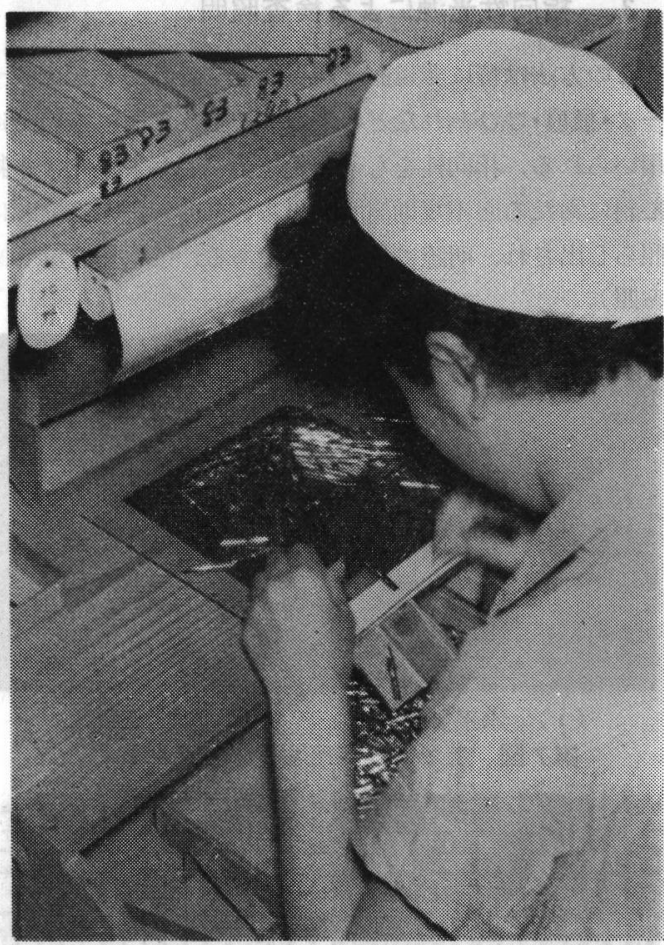

第13図ぺン先の検查 (エレガントペン先株式会社)

硝子上に置き光源面の明るさとペンの陰との対比により 形状を判別している. 上部に取付けられているのはめっ き，筋，先のそろい力，を検査するための10W㡺光色け い光灯で前記検查の場合は消灯する.

例12 (第14図) 鋼球の表面検査の例で，20W 白色け 


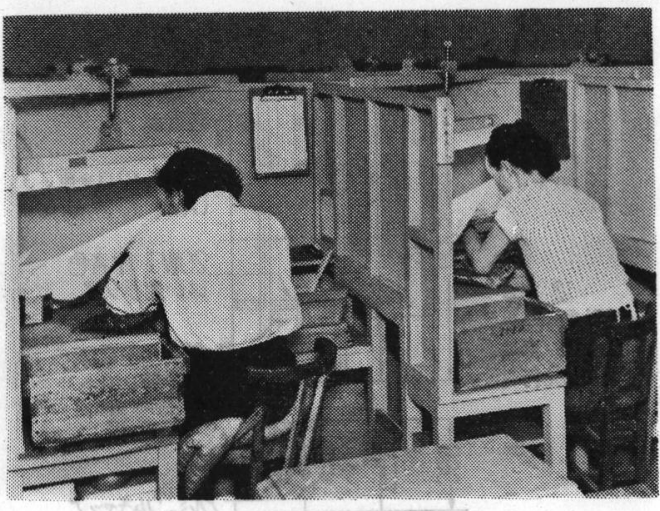

第14図 鋼 球 9 表面検查

（株式会社 天辻鋼球製作所）

い光灯 2 本の前面に乳白色合成樹脂の薄板を置いたもの を光源とし，乳白ガラスを底にしたさら上に鋼球を置き さらを動かしつつ球面のきづ，さび，脱炭などによるく もりを検查する. 作業面照度 $10001 x$.

外国文献には白熱電球を用い白色塗装した板を直角に 組合せてその反射を利用している例がある。なお，無空 とし，室内を暗くしているが，これは不必要な鏡面反射 をなくなすためと空気調節に好都合のためと考えられ る.

\section{5 特殊光源・特殊手法による検査照明}

特殊な光源を用いるか，特殊な光学的手法を用いてふ つうの照明では見光難いかあるいは全く見えない検査対 象を，対比とか大きさを特に増大して検査する方法，ま たは光色に関し特別な要求をみたすために工夫せられた 光源を用いる，検查照明をここで総括してとりあげる が, 現在実用化されているものはおおよそ次の通りであ る.
a. 光学的拡大法
b. 色光の利用
c. 天然色光源の使用
d. けい光反応の利用
e. 偏光の応用
f. ストロボ効果の利用

\section{5 .1 光学的拡大法}

光学的拡大法として凸レンズを用いる事は常識である がサークライン・ランプとレンズとを組合せると非常に 細かい作業に便利な器具となる. (第15図参照) 特に倍 率を高めるものに投映拡大器があり針先や菌車の検査な ぞに使用されているがこれは前記の通り検查照明の対象 外とする。

\section{5 .2 色光の \\ 利用}

色彩印刷において 校正刷の検査は困難 な作業の一つである が検查対象の色と補 色の関係にある色光 を使用すると印刷部 分はそれを吸収して

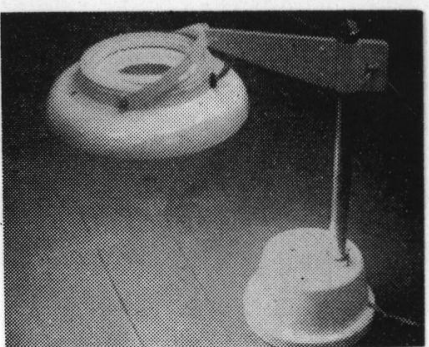

第15図 サークライン・ラン プと凸レンズの組合せ器具
暗く見え，白い背景はその大部分を反射するので普通電 灯で見るより対比が大となり細部が見易くなる。すなる ち青色光は黄検査, 緑色光は赤検査, 赤色光は青検査に 用いる．照明器具としては種々な色のけい光灯を組合せ たものを屋根型に配置し, 点滅出来るようにすれば便利 である。

色光はまた金属工場でも用いられニッケルにクロー 厶鍍金をかけるとき，鍍金の不完全部は昼光色けい光灯 のようなやや青味ががった光線で照らすと，その部分の 色が強められて発見が容易になる。金属のさびも緑色け い光灯によると明膫になる。

\subsection{3 天然色光源の使用}

天然の㡺光により検査する事が基準とされる場合，北 悹光を使用するとしてもその照度ならびに分光エネルギ 一分布が相当変化するので，一定条件を必要とする場合 の人工光源が種々考案されている.

その代衣的なものは
a. 演色性を改善したけい光灯
b. 白熱灯にフイルターをかけたもの
c. けい光灯を組合せたもの
d. 白熱灯とけい光灯を組合せたるの

で, 次にその実例を示す.

例13 (第16図) 敷物の検查照明施設で光 源は 40W 、光灯 2 灯用器具 3 連を 2 列床面 (検查面) 上約 $3 \mathrm{~m}$ r 間隔 $2.5 \mathrm{~m}$ で配置し天然昼光色を使用している. 作業面 照度は 300 400 1x.

例14 (第17図) 布の染色検查に用いる 標 準光源の例 で, 中央の方形器具は $300 \mathrm{~W}$ 標準タングステン電球 8 灯 にフイルターをかけ色温度を $6500^{\circ} \mathrm{K}$ に調整した近似 C 光源で下面には厚さ $3 \mathrm{~mm}$ の拡散板ガラス（拡散率80\%) がはめてある. 照度は器具の下 4 尺で $9001 \mathrm{x}$ ．周囲の 4 灯は150W の標準タングステン電球で $\mathrm{A}$ 光源をなし同様 の拡散ガラスを通して 4 尺下で $950 \mathrm{~lx}$ となっている.

例15 (第18図) 従来の北空光に代り採用されている 綿糸検査用照明器具で， $40 \mathrm{~W}$ 昼光色けい光灯と $40 \mathrm{~W}$ 天然 昼光色けい光灯とを 1 本ずっ組合せ，灯の前面に拡散ガ ラスを使用して照度の均一化を計ってある．検査面照度 


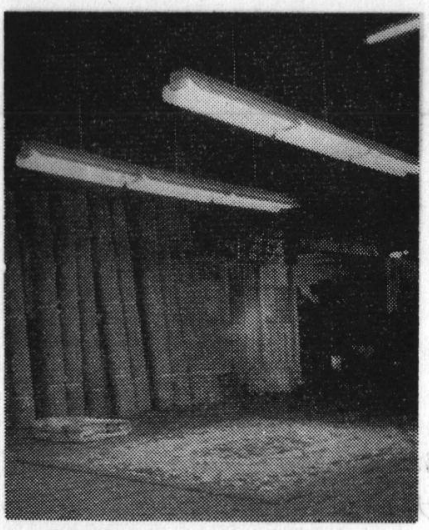

第16図 敷物の検査照明 (輪出敷物検査協会)

\subsection{4 けい光反応の利用}

近紫外線によりけい光物質はけい光を発するが，これ を利用する幾多の検查法がある．光源としてはプラック

・ライト・ランプか水銀灯によるスポツト・ランプにブ

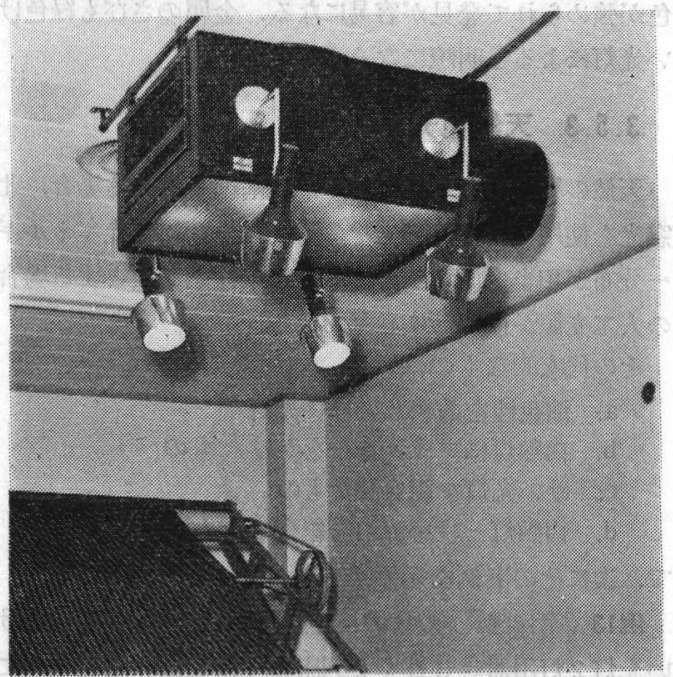

第17図 染色 検 查 用 光 源 （日本紡績検查協会）

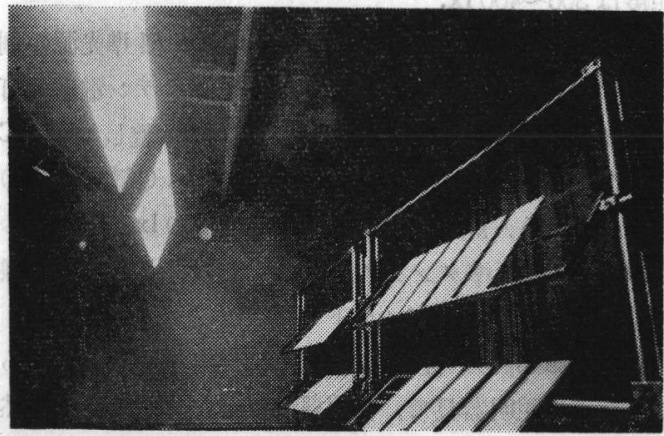

第18図糸の節むら检查装置 （日本紡績検查協会）

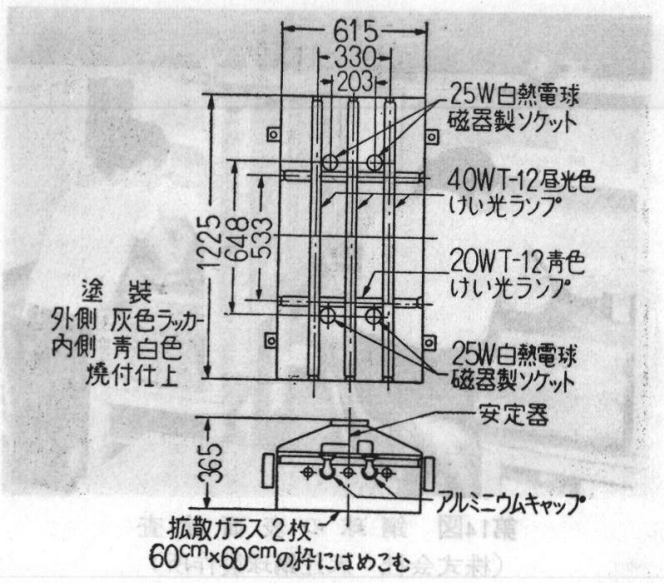

第19因 原線格付検查用照明器具

I. E., OCT. 1953(I. E. S. Lightingdatasheet 6-21)

ラック・ライト・フイルターをかけたものが用いられる。 たとえば鉄など強磁性体製品の割れ検査で磁化した被検 查物にけい光性強磁性粉末を懸濁した油を吹付けると漏 洩磁束により割れ箇所に磁性粉末が集るため,ブラック ・ライトでそれが明瞭に照らし出される。 また金属, 多 孔性でない合成樹脂, 陶器等の表面にけい光性渗透液を 塗布して拭い去れば，割れ箇所，極めて小さな表面きゔ などにけい光物質が残りそれがブラック・ライトではつ きり見える．この他に繊維工業，化学工業などでも広い 用途がある。

\section{5 .5 偏光の応用}

偏光を用いるとビン,真空管, レンズ,灯管ステムなど ガラス製品の内部歪は色のついたしま模様となって現れ るのでこれらの検査に用いられている. また金属材料の 内部歪の状況も，ガラス，七ルロイド，合成樹脂などの 透明物質でこれと同型の模型を作り荷重を加えたときの 偏光検査で，金属材料内に発生する歪を推測できること は光弾性学として周知のものである.

\subsection{6 ストロポ効果の利用}

周期的に振動または回転する物体の視検査はその周期 が大となると普通の光源では不可能になる，そこで従来 用いられているのがストロボで第20図はエンヂンの回転 中の検査を $10 \mathrm{~W} け い$ 光灯によるストロボ光で行ってい る所である. この光源の可変周波数 範囲は 400 14,000 $\mathrm{c} / \mathrm{s}$ で, フライ・ホィールの検査には約 $1,000 \mathrm{c} / \mathrm{s}$, 弁のス プリング振動状態を見るには $5,000 \sim 6,000 \mathrm{c} / \mathrm{s}$, を使用 している.

\section{あとがき}

最初に限定した範囲でも検査照明手法は多種多様であ 


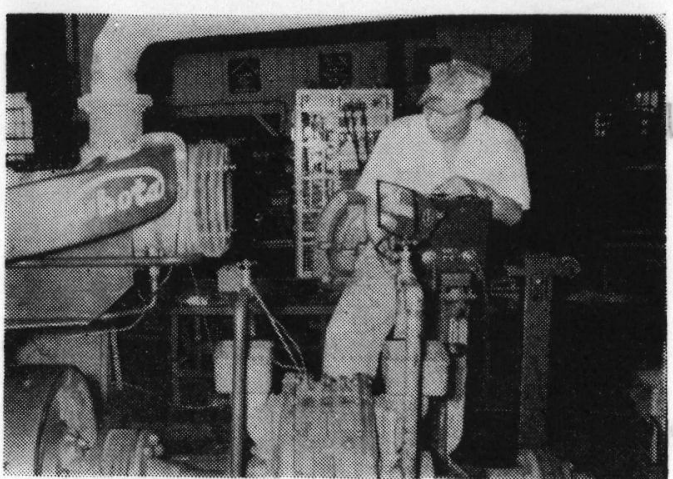

第20図ストロボによるエンヂンの検査

り一応以上の通り分類して解説したが現実の施設の中に
はそれほど明確に区別出来ぬものも多く，また入手出来 た僅かの資料を活用する意図で形態的な主点にもとらい てあえて例としたものもある事を断りする。

検査照明の題目のもとでは設計上の本質的な問題をと り上げるのが本筋かとも思はれるが，それに至る前に先 ゔ実用されている照明手法を類型的に考察しておくのも 無意味ではないと考えて執筆した．諸賢の御叱教を願う 之共に，撮影を許可されたり，資料提出に御協力願った 各位,なお撮影担当を願った当所大槻技師に深謝を表す る次第である.

なお本文中外国資料とあるは米国照明学会発行の Recommended Practice for Supplementary Lighting（1953）であることを附記する。

(32-10-11 受付)
新刊紹介

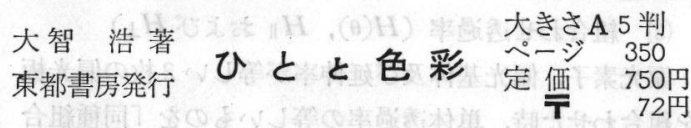

著者は色彩の専門家として長年にわたって教壇に立ち また多くの著書をも持っている方である。こんどは『ひ とと色彩』というものを書いている。とれは序文でもい っているように，なにか手引きになるような色彩書を， という希望をもっていたので，心がけていた原稿をまと めたものであるという.

したがって，実に細かい点に注意が払われており，内 容もきわめて広く，理論や学説を交じて随筆的に興味本 位にまとめているので，手引きになることはたしかであ る、これを読んでいると自分が色彩学者にでもなったか のような錯覚を起すほどである。

内容は7部にわかれており，第1 部暮しの色彩，第 2 部色とはなにか，第 3 部色の調和，第 4 部産業と色彩, 第 5 部色彩調節, 第 6 部社会環境の色, 第 7 部色彩学の 回顧，それに参考文献，人名索引，事項索引などを入れ てあり，なかなか親切な本で，要所または色図版もあっ てよいが，読者の対象を万能的にとっている点，少し慾 が深すぎる.もう少し焦点を絞って家庭に抢くか.ある いは事業方面に拉くかしたら，同じ指導的な意味をもつ ものであっても，すっきりした色彩書になったかも知れ ないしかしいろいる問題はあるにしても，色彩学の一般 書として1 冊は備えておいてよい著書である。

（須田棟介）

\section{照明界のトピックス}

\section{専門会員小西彦噟君の退職と表彰}

本会参事, 小西彦麿君は去る昭和32年11月30日満70才 の高齢をもって学会事務局を退職された. 11月29日は学 会の創立記念日であり，当日普及会の創立総会が開かれ

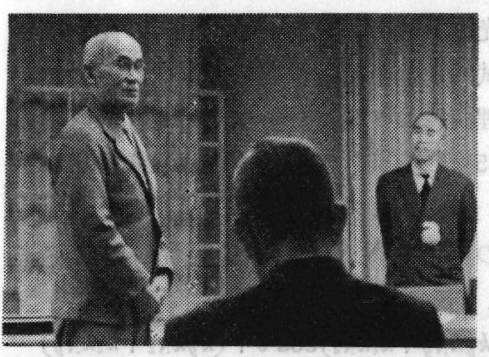
たが, 総会直 後その席を利 用して小西参 事の表彰式が 行われた。

同氏は昭和 20 年 12 月以来 12 年間, 精 励，格勤ことに終戦直後の混乱期に当り，学会の存否も 危ぶまれた折柄よく再建に協力せられ，今日の基檚を築 かれたものであり，本城会長より表彰状と金一封が受与 された。

尚, 同氏の後任としては東光電気の熊岡誠一君か゚12月 20日就任された。

\section{日本色彩文化センターの発足}

最近各方面に色彩の標準化など色に関する科学が浸透 して来たが，色彩関係の諸団体の連絡調整をはかり，色 彩技術を普及するために学者，色彩技術者，製造業者な どを一丸とした日本色彩文化センターが昭和 32 年 12 月 5 日から発足した。

事務所は当分の間, 麻布霞町の色彩文化会館内におか れ，会長には日本色彩研究所長和田三造氏が就任し，色 彩科学の発達を推進することになっている。. 